\title{
Analisis Pola Asuh Orang Tua Terhadap Motivasi Belajar Siswa
}

\author{
Tri Nur Fadhilah ${ }^{1}$, Diana Endah Handayani ${ }^{2}$, Rofian $^{3}$ \\ 1,2,3 Jurusan Pendidikan Guru Sekolah Dasar, Fakultas IImu Pendidikan \\ Universitas PGRI Semarang \\ e-mail: trinur459@gmail.com, handayani.hitam@gmail.com, kotakomik.pian@gmail.com
}

\begin{abstract}
Abstrak
Penelitian ini bertujuan untuk mengetahui bagaimana pola asuh yang diterapkan oleh orang tua terhadap motivasi belajar siswa kelas IV SD Negeri 01 Wonogiri Kabupaten Pemalang tahun pelajaran 2018/2019. Jenis penelitian ini adalah kualitatif. Sampel dalam penelitian ini adalah 6 siswa kelas IV. Metode pengumpulan data yang digunakan yaitu observasi, wawancara dan dokumen. Teknik analisis data yang digunakan adalah analisis deskriptif. Hasil penelitian menunjukkan bahwa terdapat pola asuh berbeda-beda yang diterapkan orang tua. Pola asuh demokratis lebih banyak diterapkan oleh orang tua, menyusul pola asuh otoriter dan permisif. 4 orang tua dengan pola asuh demokratis, 1 orang tua dengan pola asuh otoriter dan 1 orang tua dengan pola asuh permisif. Siswa dengan pola asuh otoriter dan demokratis mempuyai motivasi belajar yang baik dan cukup. Sedangkan siswa dengan pola asuh permisif mempunyai motivasi yang kurang. Berdasarkan penelitian, dapat disimpulkan bahwa pola asuh dan peran serta orang tua berpengaruh terhadap motivasi belajar siswa.
\end{abstract}

Kata Kunci: Motivasi belajar siswa, pola asuh orang tua

\begin{abstract}
This study aims to find out how parenting is applied by parents to the learning motivation of Grade IV students of SD Negeri 01 Wonogiri Pemalang Regency 2018/2019. This type of research is qualitative. The sample in this study were 6 fourth grade students. Data collection methods used are observation, interviews, and documents. The data analysis technique used is descriptive analysis. The results showed that there were different parenting styles applied by parents. Democratic parenting is more applied by parents, following authoritarian and permissive parenting. 4 parents with democratic parenting, 1 parent with authoritarian parenting and 1 parent with permissive parenting. Students with authoritarian and democratic parenting have good and sufficient learning motivation. While students with permissive parenting have less motivation. Based on the research, it can be concluded that parenting and parental participation influence student learning motivation.
\end{abstract}

Keywords: Parenting parents, student's motivation to study 


\section{Pendahuluan}

Pasal 1 UU SISDIKNAS no. 20 tahun 2003 disebutkan bahwa Sistem Pendidikan Nasional adalah keseluruhan komponen pendidikan yang saling terkait secara terpadu untuk mencapai tujuan pendidikan nasional. Berangkat dari bunyi pasal ini dapat diketahui bahwa pendidikan adalah sistem yang merupakan suatu totalitas struktur yang terdiri dari komponen yang saling terkait dan secara bersama menuju kepada tercapainya tujuan (Soetarno, 2003: 2). Adapun komponen-komponen dalam pendidikan nasional antara lain adalah lingkungan, sarana-prasarana, sumberdaya, dan masyarakat. Komponen-komponen tersebut bekerja secara bersama-sama, saling terkait dan mendukung dalam mencapai tujuan pendidikan (Munirah ,2015).

Pendidikan merupakan salah satu hal terpenting bagi manusia.Baik pendidikan formal maupun non formal mampu membentuk kepribadian manusia lebih baik, sopan, cerdas, sukses, bertanggungjawab dan membawa arah ke negara yang lebih maju lagi.Oleh karena pentingnya pendidikan, banyak orang yang pergi keluar daerah bahkan ke luar negeri demi keberhasilan pendidikan yang mereka inginkan.Salah satu faktor penting untuk berhasil dalam pendidikan mampu belajar adalah motivasi belajar (Arumsari ,2017).

Keluarga merupakan beberapa individu yang tergabung dalam satu rumah tangga yang sama karena hubungan darah. Di dalam keluarga terdiri dari ayah, ibu dan anak dalam suatu unit masyarakat kecil. Menurut Soelaeman (dalam Djamarah, 2014: 19) mengatakan bahwa "keluarga adalah sekumpulan orang yang hidup bersama dalam tempat tinggal bersama dan masing-masing anggota merasakan adanya pertautan batin sehingga terjadi saling mempengaruhi, saling memperhatikan, dan saling menyerahkan diri".

Orang tua dan anak adalah satu ikatan dalam jiwa. Setiap orang tua yang memiliki anak selalu ingin memelihara, membesarkan, dan mendidiknya. Menurut Djamarah (2014: 44) mengatakan bahwa orang tua dan anak dalam satu keluarga memiliki kedudukan yang berbeda. Dalam pandangan orang tua, anak adalah buah hati dan tumpuan masa depan yang harus dibimbing dan diasuh. Membimbing dengan cara membantu, melatih dan sebagainya, dan mengasuh dalam arti menjaga dengan cara merawat, memelihara dan mendidiknya agar menjadi anak yang cerdas.

Setiap orang tua mempunyai cara yang berbeda-beda untuk mendidik anak dalam keluarga. Menurut Baumrind (dalam Wibowo \& Gunawan, 2015: 62) ada tiga jenis pola asuh, yaitu: 1) pola asuh otoriter; 2) pola asuh demokratis; dan 3) pola asuh permisif. Pola asuh otoriter adalah pola asuh yang keras, orang tua cenderung memaksakan kehendak ke anak tanpa banyak alasan. Ciri khas pola asuh ini diantaranya, orang tua sangat dominan dalam kekuasan dan kontrol dari orang tua terhadap tingkah laku anak sangat ketat. Pola asuh demokratis adalah pola asuh yang bertolak belakang dengan pola asuh otoriter. Orang tua memberikan kebebasan pada anak dan mendorong anak untuk mandiri. Orang tua senantiasa memberikan dorongan positif untuk membimbing anak ke arah yang lebih baik. Pola asuh permisif adalah pola asuh yang membebaskan anak namun tidak dalam pengawasan orang tua, bahkan kontrol dan perhatian orang tua terhadap anak sangat kurang. Kelebihan pola asuh permisif ini anak bisa menentukan apa yang mereka inginkan. Namun, jika anak tidak dapat mengontrol dan mengendalikan diri sendiri, mereka justru akan terjerumus ke hal-hal yang negatif.

Penerapan pola asuh orang tua dapat mempengaruhi kebiasaan belajar siswa baik di rumah maupun di sekolah. Karena orang tua merupakan guru pertama dan utama bagi anak. Sebagai orang tua sudah seharusnya memberi bekal anaknya kelak untuk membentuk generasi masa depan yang berkualitas. Seperti yang tercantum dalam Undang-Undang Nomor 20 tahun 2003 Tentang Sistem Pendidikan Nasional pasal 7 ayat 2 menyatakan bahwa "Orang tua dari anak usia wajib belajar, berkewajiban memberikan pendidikan dasar kepada anaknya". Karena pendidikan anak pada hakikatnya adalah tanggung jawab orang tua. Menurut Undang-Undang Nomor 20 Tahun 2003 pasal 13 ayat 1 menyatakan bahwa "jalur pendidikan terdiri atas pendidikan formal, informal, dan nonformal yang dapat saling melengkapi dan memperkarya". Pendidikan formal adalah jalur pendidikan sekolah. Pendidikan informal adalah pendidikan yang ada di dalam keluarga. Pendidikan nonformal adalah jalur pendidikan lingkungan atau masyarakat.

Keberhasilan anak di sekolah harus didukung oleh perhatian orang tua. Orang tua merupakan faktor eksternal yang mempunyai peranan utama dalam mendidik anak untuk mencapai prestasi belajar melalui motivasi yang di berikan orang tua. Menurut Slameto (2010: 60) "cara orang tua mendidik anaknya besar pengaruhnya terhadap belajar anaknya". Orang 
tua yang kurang memperhatikan pendidikan anaknya, seperti tidak mendampingi anak belajar, tidak tahu kesulitan-kesulitan yang dialami dalam belajar, dan lain-lain, dapat menyebabkan anak tidak berhasil dalam belajarnya. Hal ini dapat terjadi pada anak dari keluarga yang orang tuanya terlalu sibuk mengurus pekerjaan. Kurangnya perhatian orang tua akan mempengaruhi prestasi belajar anak.

Menurut Slameto (2010: 54-60) faktor yang mempengaruhi belajar dibedakan menjadi dua yaitu, faktor intern dan faktor ekstern. Faktor intern adalah faktor yang berasal dari dalam diri siswa (jasmaniah, psikologis, dan kelelahan). Sedangkan faktor ekstern adalah faktor yang berasal dari luar (keluarga, sekolah dan masyarakat).

Salah satu faktor yang terdapat dalam diri siswa adalah motivasi belajar. Menurut Sadirman (2005: 75) menyatakan "motivasi dapat dikatakan sebagai keseluruhan daya penggerak di dalam diri siswa yang menimbulkan kegiatan belajar, yang menjamin kelangsungan dari kegiatan belajar mengajar dan yang memberikan arah pada kegiatan belajar, sehingga tujuan yang dikehendaki oleh subjek belajar itu dapat tercapai". Siswa akan mencapai keberhasilan apabila ada keinginan dalam dirinya untuk belajar. Siswa yang mempunyai keinginan untuk belajar akan berpengaruh pada kegiatan belajar di sekolah.

Motivasi merupakan pendorong bagi mahasiswa untuk melakukan sesuatu. Motivasi dapat medorong seseorang, sehingga akhirnya orang itu menjadi spesialis dalam bidang ilmu pengetahuan tertentu. Tidak mungkin seseorang mau berusaha mempelajari sesuatu dengan sebaik-baiknya jika ia tidak mengetahui betapa penting dan faedahnya hasil yang akan dicapai dari belajarnya bagi dirinya (Purwanto, 2006). Dalam proses belajar pun minat sangat diperlukan, sebab seseorang yang tidak memiliki minat belajar tidak mungkin melakukan aktivitas belajar. Minat adalah "gejala yang tertarik pada sesuatu yang selanjutnya minat seseorang akan mencerminkan tujuannya". Apabila mahasiswa yang berminat terhadap suatu pelajaran tertentu dapat dilihat dan diamati partisipasinya dalam menekuni pelajaran tersebut. Minat ini memegang peranan penting dalam proses belajar mengajar, tanpa adanya minat maka ia tidak dapat menguasai pelajaran yang diberikan dosennya (Syardiansah ,2016).

Motivasi menurut Mangkuprawira dan Hubeis (2007: 113) merupakan dorongan yang membuat karyawan melakukan sesuatu dengan cara dan untuk mencapai tujuan tertentu. Motivasi dalam bahasa Inggris disebut motivation yang berasal dari bahasa latin movere yang dimaksud menggerakkan (Palupi, 2014).

Sudarwan (2002:2) motivasi diartikan sebagai kekuatan, dorongan, kebutuhan, semangat, tekanan, atau mekanisme psikologis yang mendorong seseorang atau sekelompok orang untuk mencapai prestasi tertentu sesuai dengan apa yang dikehendakinya. Hakim (2007:26) mengemukakan pengertian motivasi adalah suatu dorongan kehendak yang menyebabkan seseorang melakukan suatu perbuatan untuk mencapai tujuan tertentu Huitt,W. (2001) mengatakan motivasi adalah suatu kondisi atau status internal (kadang-kadang diartikan sebagai kebutuhan, keinginan, atau hasrat) yang mengarahkan perilaku seseorang untuk aktif bertindak dalam rangka mencapai suatu tujuan. Ditambahkan Gray (Winardi, 2002) mengemukakan bahwa motivasi merupakan sejumlah proses, yang bersifat internal atau eksternal bagi seorang individu, yang menyebabkan timbulnya sikap antusiasme dan persistensi, dalam hal melaksanakan kegiatan- kegiatan tertentu (Suprihatin, 2015).

Berdasarkan observasi serta wawancara dengan guru kelas IV, hasil survei menunjukkan bahwa siswa di kelas IV memiliki motivasi belajar yang sedang. Hal ini terlihat pada saat pembelajaran berlangsung sebagian siswa kurang menunjukkan minatnya dalam proses pembelajaran. Sebagian siswa lebih senang mengganggu temannya dan tidak memperhatikan guru mengajar. Saat diberi tugas oleh guru, siswa sering sibuk sendiri sehingga tugas tidak terselesaikan dengan cepat. Terdapat beberapa siswa yang kurang semangat dalam mengikuti pelajaran. Pada saat pembelajaran di kelas, ada beberapa siswa yang tidak memperhatikan penjelasan dari guru dan dilihat dari hasil ulangan harian banyak siswa yang belum mencapai KKM.

Kesadaran orang tua akan peran dan tanggung jawabnya selaku pendidik yang pertama dan utama dalam keluarga sangat diperlukan. Beberapa faktor penyebab rendahnya motivasi belajar siswa dapat dilihat latar belakang orang tua siswa yang berbeda-beda, baik dari segi pekerjaan atau kesibukan, kondisi ekonomi dan lain-lain yang mempengaruhi kurangnya perhatian kepada anak-anaknya sehingga anak dipasrahkan penuh ke pihak sekolah. Didukung oleh Djamarah (2014: 52) menyatakan bahwa bervariasinya pola asuh itu dipengaruhi oleh latar belakang pendidikan orang tua, mata pencaharian hidup, keadaan sosial ekonomi, adat istiadat, suku bangsa, dan sebagainya. Secara umum pekerjaan orang tua siswa ada yang bekerja sebagai guru tetapi mayoritas sebagai buruh, petani dan pedagang. Hal ini dapat berpengaruh 
dalam motivasi belajar, orang tua yang sibuk dengan pekerjaannya anak akan mendapatkan perhatian yang kurang dalam hal belajar. Berbeda dengan orang tua yang pekerjaannya tidak terlalu sibuk, mereka akan ikut serta memantau anak pada saat belajar di rumah.

Adapun tujuan dari penelitian ini adalah untuk mengetahui peran dan pola asuh orang tua terhadap motivasi belajar siswa SD Negeri 01 Wonogiri Kabupaten Pemalang.

\section{Metode}

Penelitian ini dilakukan dengan pendekatan kualitatif. Teknik yang digunakan adalah analisis deskriptif untuk menjelaskan peran dan pola asuh orang tua yang diterapkan terhadap motivasi belajar siswa. Tujuannya adalah untuk mendeskripsikan peran dan pola asuh orang tua terhadap motivasi belajar siswa SD Negeri 01 Wonogiri Kabupaten Pemalang.

Sampel dalam penelitian ini sebanyak 6 siswa kelas IV beserta orang tuanya. Alasan mengambil 6 sampel siswa tersebut karena berdasarkan data yang didapat dari guru mengenai tingkat prestasi belajar siswa tersebut di sekolah. Teknik pengumpulan data dengan menggunakan obervasi, wawancara dan dokumen.

\section{Hasil dan Pembahasan}

Dari Penelitian ini dilakukan mulai dari tanggal 5-10 April 2019 di SD Negeri 01 Wonogiri. Berdasarkan hasil wawancara terdapat perbedaan motivasi antara siswa di kelas IV. Peneliti mengambil sampel 6 siswa beserta orang tua dengan motivasi kategori tinggi, sedang dan rendah.

Tabel 1. Rekapitulasi Pola Asuh orang tua terhadap motivasi belajar

\begin{tabular}{llc}
\hline $\begin{array}{l}\text { Nama } \\
\text { Siswa }\end{array}$ & $\begin{array}{l}\text { Pola Asuh } \\
\text { Orang Tua }\end{array}$ & $\begin{array}{c}\text { Motivasi } \\
\text { Belajar }\end{array}$ \\
\hline Haryo & Demokratis & Tinggi \\
\hline Anisa & Demokratis & Tinggi \\
\hline Dirli & Otoriter & Sedang \\
\hline Yogida & Demokratis & Sedang \\
\hline Siti & Permisif & Rendah \\
\hline Vino & Demokratis & Rendah \\
\hline
\end{tabular}

Berdasarkan analisis data yang telah dilakukan, dapat dijelaskan tentang bentuk-bentuk pola asuh yang ditemui terhadap motivasi belajar siswa. Dari hasil yang ditemui di lapangan dapat diketahui bahwa ada orang tua yang menerapkan pola asuh demokratis, anak dari orang tua yang menanamkan bentuk pola asuh demokratis dapat dilihat bahwa motivasi di kelas termasuk kategori tinggi dan anak tersebut juga berprestasi di sekolah.

Berdasarkan hasil yang diperoleh juga ditemukan ada orang tua yang menerapkan pola asuh otoriter, dimana pola asuh otoriter dapat menyebabkan kesulitan bagi anak untuk bersosialisasi. Karena dalam mengasuh anak orang tua banyak memberikan larangan, perintah dan harus disiplin.

Berdasarkan analisis data yang dilakukan beberapa temuan dilapangan dapat dikatakan bahwa bentuk pola asuh orang tua permisif kurang tepat digunakan. Karena dapat berdampak buruk bagi anak yang berakibat motivasi di dalam kelas kurang. Ada beberapa faktor yang menyebabkan orang tua menerapkan bentuk-bentuk pola asuh diantaranya usia orang tua, keterlibatan orang tua, pendidikan orang tua, pengalaman dalam mengasuh anak, stress orang tu, dan hubungan suami isteri (Tridhonanto, 2014: 24-28). Selain itu juga disebabkan karena faktor lingkungan dan budaya yang dapat mempengaruhi pola asuh.

Tabel 2. Latar Belakang Pendidikan dan Pekerjaan Orang Tua

\begin{tabular}{lcl}
\hline \multicolumn{1}{c}{ Nama Siswa } & $\begin{array}{c}\text { Latar Belakang } \\
\text { Pendidikan Orang Tua }\end{array}$ & Pekerjaan orang Tua \\
\hline Haryo & S1 & Guru \\
\hline Anisa & SMP & Pedagang \\
\hline Dirli & SMA & Pedagang \\
\hline
\end{tabular}




\begin{tabular}{lll} 
Yogida & SMA & IRT \\
\hline Siti & SD & Petani \\
\hline Vino & SMP & Penjahit \\
\hline
\end{tabular}

Berdasarkan temuan yang diperoleh dilapangan, terhadap bentuk pola asuh demokratis ada tiga orang tua yang sama-sama menerapkan pola asuh demokratis, dalam mengasuh anak mereka memberikan kebebasan untuk melakukan sesuatu tetapi masih dalam pantauan orang tua. Dari ketiga orang tua ini, ada salah satu dari anak mereka yang termasuk kategori memiliki motivasi rendah. Hal ini disebabkan karena dalam tingkat kecerdasan dari anak kurang. Selain itu perilaku anak di kelas saat pembelajaran tidak memperhatikan penjelasan dari guru dan lebih suka berbicara serta bermain sendiri dengan teman sebangkunya. Apabila guru memberikan tugas anak tersebut tidak mengerjakan tugas dengan segera dan sering terlambat menyelesaikan tugas. Berbeda dengan dua anak yang orang tuanya menerapkan pola asuh demokratis, mereka cenderung memiliki motivasi yang dikategorikan tinggi. Hal ini disebabkan karena tingkat kecerdasan anak yang tinggi dan kebiasaan belajar di rumah maupun di sekolah.

Syamaun (2012: 28-29) mengemukakan bahwa "ciri tipe demokratis adalah menerima, kooperatif, terbuka terhadap anak, mengajar anak untuk mengembangkan disiplin diri, jujur dan ikhlas dalam menghadapi masalah anak-anak, memberikan penghargaan positif kepada anak tanpa dibuat-buat, mengajarkan kepada anak untuk mengembangkan tanggung jawab atas setiap perilaku dan tindakannya, bersikap akrab dan adil, tidak cepat menyalahkan, memberikan kasih sayang dan kemesraan kepada anak". Ciri-ciri orang tua yang seperti ini merupakan refleksi dari kondisi kepribadian yang matang, dewasa, sehat dan normal. Pola demokratis cenderung membebaskan anak melakukan kegiatan apa saja tetapi masih dalam pendampingan dan pantauan dari orang tua.

Temuan penelitian yang diperoleh dari hasil observasi dan wawancara yang dilakukan terhadap orang tua dan anak, ada salah satu orang tua menerapkan pola asuh otoriter. Dalam mengelola pola asuhnya beliau menerapkan dengan keras, disiplin, banyak aturan yang harus dipatuhi oleh anak dan memberi hukuman ketika anak melanggar peraturan tersebut. hukuman yang diberikan dapat berupa tidak diperbolehkan main dan keluar rumah. Faktor yang mempengaruhi pola asuh orang tua adalah lingkungan. Karena anak mudah terpengaruh terhadap lingkungan, maka orang tua menerapkan bentuk pola asuh otoriter. Menurut Wibowo dan Gunawan (2015: 62) mengatakan bahwa "pola asuh otoriter adalah pola asuh yang keras, orang tua cenderung memaksakan kehendak ke anak tanpa banyak alasan.

Berdasarkan hasil penelitian ini terlihat jelas bahwa bentuk pola asuh demokratislah yang paling dominan di terapkan oleh orang tua, walaupun ada orang tua yang menerapkan pola asuh otoriter. Selain itu temuan penelitian yang diperoleh dari informan, ada orang tua yang menerapkan pola asuh permisif. Menurut Wibowo dan Gunawan (2015: 62) mengatakan bahwa "pola asuh permisif adalah pola asuh yang membebaskan anak namun tidak dalam pengawasan orang tua, bahkan kontrol dan perhatian orang tua terhadap anak sangat kurang". Anak dengan orang tua yang menerapkan pola ini sangat berpengaruh terhadap motivasi belajarnya. Saat observasi berlangsung anak tersebut terlihat kurang semangat dan lebih suka menyendiri. Hal ini disebabkan orang tua menerapkan pola asuh acuh tak acuh dengan pendidikan anak karena sibuk bekerja dan mengasuh dua anak yang masih kecil. Faktor yang mempengaruhi pola asuh yang diterapkan oleh orang tua dilihat dari latarbelakang pendidikan orang tuanya, selain itu keterlibatan orang tua terhadap anak kurang.

Dari enam orang tua dan enam anak sudah terdapat latarbelakang pekerjaan, pendidikan orang tua, karena bagaimanapun pola asuh dipengaruhi dengan faktor yaitu pekerjaan dan pendidikan orang tua, lingkungan sekitar, dan sebagainya. Artinya, pekerjaan, pendidikan, lingkungan sangat berpengaruh pada pola asuh. Jadi akan mengetahui pola asuh seperti apa yang diterapkan orang tua berdasarkan pekerjaan, pendidikan orang tua dan lingkungan sekitar. Dari macam-macam pola asuh itu dikaitkan dengan motivasi belajar anak. Selain itu ada faktor-faktor yang mempengaruhi pola asuh yang di terapkan orang tua.

Sikap orang tua yang selalu memerhatikan kemajuan belajar anaknya, akan mendorong anak untuk lebih semangat dalam belajar. Perhatian dan peran orang tua memang sangat dibutuhkan oleh anak. Karena dalam usia ini, mereka belum mampu mandiri dalam segala hal, termasuk dalam hal belajar.

Pola asuh yang dapat meningkatkan motivasi belajar yaitu demokratis. Karena demokratis sifatnya bebas dalam arti memberikan kebebasan anak untuk bereksplorasi/ mengeksplorasi bakatnya, minatnya sehingga anak itu merasa bebas berprestasi dan tidak ada tekanan. Tetapi demokratis juga ada kekurangan, kalau anak tidak pintar mengontrol diri maka 
anak menjadi liar. Jadi demokratis itu masih dalam pendampingan dan pantauan dari orang tua. Menurut Thomas Gordon (dalam Syamaun, 2012: 28-29) mengatakan bahwa ciri-ciri orang tua seperti ini merupakan refleksi dari kondisi kepribadian yang matang, dewasa, sehat, profuktif, normal dan tidak mengalami hambatan.

Berdasarkan analisis data yang dilakukan maka ditemukan hasil penelitian tentang bentuk pola asuh yang diterapkan oleh orang tua terhadap motivasi belajar siswa kelas IV SD Negeri 01 Wonogiri Kabupaten Pemalang. Hal ini tergambar dari hasil observasi dan wawancara dengan orang tua dan anak, dimana bentuk pola asuh yang dominan diterapkan oleh orang tua yaitu pola asuh demokratis. Selain bentuk pola asuh demokratis, ada juga yang menerapkan pola asuh otoriter dan pola asuh permisif.

\section{Simpulan dan Saran}

Berdasarkan temuan hasil analisis penelitian dan pembahasan dapat disimpulkan bahwa dari data hasil penelitian, peneliti menemukan tiga pola asuh yang diterapkan oleh orang tua siswa yang menjadi fokus penelitian yaitu, pola asuh otoriter, pola asuh demokratis, dan pola asuh permisif. Pola asuh demokratis lebih banyak diterapkan oleh orang tua, menyusul pola asuh otoriter dan permisif. Pola asuh dan peran serta orang tua berpengaruh terhadap motivasi belajar siswa. Siswa dengan pola asuh otoriter dan demokratis mempuyai motivasi belajar yang baik dan cukup. Siswa dengan pola asuh permisif mempunyai motivasi yang kurang.

Penerapan pola asuh yang baik dapat diwujudkan lewat perlakuan, perhatian, pemenuhan kebutuhan, serta sikap orang tua dalam kehidupan sehari-hari dapat berpengaruh terhadap prestasi belajar anak di sekolah. Jenis pola asuh yang diterapkan oleh orang tua dapat berpengaruh terhadap karakteristik anak dikemudian hari. Memberikan sikap yang positif, perlakuan yang sesuai dari orang tua dalam mendidik anak, maka akan lebih mudah meningkatkan motivasi anak dalam belajar.

Berdasarkan hasil penelitian saran yang dapat disampaikan bagi orang tua dapat memberikan pola asuh yang tepat dan memberi perhatian serta dukungan penuh terhadap kegiatan positif anak agar anak menjadi lebih termotivasi lagi dalam belajranya, sehingga anak dapat mengembangkan bakat yang dimilikinya. Bagi siswa, dapat menjadi bahan masukan bagi siswa agar lebih giat lagi dalam mengikuti pembelajaran agar mencapai suatu prestasi. Bagi guru, dapat memberikan informasi bahwa peran oran tua mempunyai pengaruh yang positif terhadap motivasi belajar siswa dan dapat bekerja sama dengan orang tua siswa dalam memberikan bimbingan serta arahan kepada anak didiknya agar mencapai keberhasilan.

\section{Daftar Pustaka}

Arumsari ,Rindang (2017). Perbedaan Motivasi Belajar Antara Siswa Yang Berasal Dari Jawa Dan Dari Papua Di Sman 1 Kediri Tahun Ajaran 2016/ 2017 . Jurnal Simki-Pedagogia Vol. 01 No. 01 Tahun 2017 ISSN : AAAA-AAAA

Djamarah, Syaiful Bahri. 2008. Psikologi Belajar. Jakarta: Asdi Mahasatya.

Djamarah, Syaiful Bahri. 2014. Pola Asuh Orang Tua dan Komunikasi dalam Keluarga. Jakarta: Rineka Cipta.

Hidayah, Siti Tsaniyatul. 2012. "Hubungan Pola Asuh Orang Tua Dengan Motivasi Belajar Siswa Kelas V MI Negeri Sindutan Temon Kulon Progo". Skripsi. UIN Sunan Kalijaga Yogyakarta.

Idrus, Ali. 2012. "Pola Asuh Orang Tua dalam Memotivasi Belajar Siswa Sekolah Dasar". Jurnal Sekolah Dasar. Pada tanggal 23 Oktober 2018 pukul 16.01 WIB.

Indonesia. Undang-Undang Sistem Pendidikan Nasional, UU No.20 Tahun 2003. Jakarta: Sekertariat Negara.

Indonesia. Undang-Undang Perlindungan Anak, UU No.35 Tahun 2002. Jakarta: Sekertariat Negara. 
Is, Jun Musnadi. 2017. "Analisis Pola Asuh Orang Tua Dengan Perkembangan Sosialisasi Remaja Di Sma Negeri 1 Kaway Xvi Kabupaten Aceh Barat". Pada tanggal 18 Oktober 2018 pukul 23.20 WIB.

Munirah (2015). SISTEM PENDIDIKAN DI INDONESIA: antara keinginan dan realita . Jurnal AULADUNA, VOL. 2 NO. 2 DESEMBER 2015

Novrinda, dkk. "Peran Orang Tua dalam Pendidikan Anak Usia Dini Ditinjau dari Latar Belakang Pendidikan". Jurnal Potensia. Pada tanggal 17 Desember 2018 pukul 12.35 WIB.

Palupi ,Retno (2014). Hubungan Antara Motivasi Belajar Dan Persepsi Siswa Terhadap Kinerja Guru Dalam Mengelola Kegiatan Belajar Dengan Hasil Belajar Ipa Siswa Kelas Viii Di Smpn N 1 Pacitan . Jurnal Teknologi Pendidikan Dan Pembelajaran Vol.2, No.2

Rofian. 2016. "Penerapan Metode Pembelajaran Demostrasi Pada Pendidikan Seni Rupa Di Sekolah Dasar". Jurnal MALIH PEDDAS. Pada tanggal 08 Mei 2019 pukul 21.34 WIB.

Sadirman, A.M. 2005. Interaksi dan Motivasi Belajar Mengajar. Jakarta: RajaGrafindo Persada.

Slameto. 2010. Belajar dan Faktor-faktor yang Mempengaruhinya. Jakarta: Rineka Cipta.

Suprihatin, Siti (2015). Upaya Guru Dalam Meningkatkan Motivasi Belajar Siswa . Jurnal Pendidikan Ekonomi FKIP Universitas Muhammadiyah Metro ISSN: 2442-9449 Vol.3.No.1

Syamaun, Nurmasyithah. 2012. Dampak Pola Asuh Orang Tua \& Guru terhadap Kecenderungan Perilaku Agresif Siswa. Jogjakarta: Ar-ruzz Media.

Syardiansah (2016). Hubungan Motivasi Belajar dan Minat Belajar terhadap Prestasi Belajar Mahasiswa Mata Kuliah Pengantar Manajemen (Studi kasus Mahasiswa Tingkat I EKM A Semester II) . Jurnal Manajemen Dan Keuangan, Vol.5, No.1, Mei 2016

Utami, Septi Nur. 2015. "Pola Asuh Orang Tua Siswa Berprestasi Di Kelas V SD Negeri Sidakan Banaran Galur Kulon Progo Tahun Ajaran 2014/2015". Skripsi. Universitas Negeri Yogyakarta.

Wibowo, Agus; Gunawan. 2015. Pendidikan Karakter Berbasis Kearifan Lokal di Sekolah. Yogyakarta: Pustaka Pelajar.

Widiasworo, Erwin. 2017. 19 Kiat Sukses Membangkitkan Motivasi Belajar Peserta Didik. Jogjakarta: Ar-ruzz Media.

Zuliani, Yayu. 2018. "Hubungan Antara Pola Asuh Orang Tua Dengan Prestasi Belajar Pada Siswa Kelas VIII di SMP PGRI 1 Ketapang Bakauheni Tahun Pelajaran 2017/2018". Skripsi. Universitas Lampung Bandar Lampung. 